\title{
APLICAÇÃO DIRETA X INDIRETA DAS NORMAS CONSTITUCIONAIS REJEIÇÃO DE ESPAÇOS DE NÃO DIREITO
}

\author{
Bruno Terra de Moraes*
}

\begin{abstract}
Sumário: Introdução - 1. Perda da centralidade do Código Civil e a supremacia da Constituição - 2. Inexistência de setores imunes à incidência constitucional: rejeição de espaços de não direito - 3. Aplicação direta x indireta das normas constitucionais às relações privadas - Conclusão - Referências.
\end{abstract}

\section{INTRODUÇÃO}

Durante muito tempo vigorou no exterior e no Brasil doutrina constitucional inspirada por uma ideologia liberal-burguesa, segundo a qual a Constituição se prestaria a, tão somente, garantir direitos dos particulares ante os abusos perpetrados pelo Estado, limitando-se, assim, o poder estatal. ${ }^{1}$

A evolução da sociedade levou a que tal concepção fosse modificada. Percebeu-se que, na realidade, a ameaça a direitos não partia, apenas, do Estado, mas se dava, também, entre particulares. Com essa percepção, tomou-se consciência de que a doutrina constitucional liberal-burguesa tradicional não mais dava conta de responder às necessidades da sociedade. Daí, então, a instituição, ao longo do Século XX, de constituiçôes em diferentes partes do mundo com cunho social e força normativa acentuados.

Procurador do Estado do Rio de Janeiro. Doutorando em Direito Civil pela Universidade do Estado do Rio de Janeiro.

1 SARMENTO, Daniel. A vinculação dos particulares aos direitos fundamentais no direito comparado e no Brasil. In: BARROSO, Luis Roberto (Org.). A reconstrução democrática do direito público no Brasil. Rio de Janeiro: Renovar, 2007, p. 293. 
O Brasil não ficou imune às transformações acima, o que se reflete no elevado componente social e no amplo leque de direitos fundamentais insculpidos na Constituição de 1988. Diante da realidade exposta, é preciso verificar como isto repercute na prática, basicamente sob dois aspectos. $\mathrm{O}$ primeiro, se refere à análise da possibilidade de existir espaços de não direito no ordenamento. Sabe-se que o legislador ordinário não regula a integralidade das relações jurídicas, seja por não vislumbrar a ocorrência de determinadas situações, seja por, deliberadamente, pretender deixá-las sem regulamentação. Nos casos de omissão involuntária por parte do legislador, há as normas de integração. Entretanto, em caso de omissão legislativa consciente, deliberada e pretendida, deve ser verificado se isto poderia acarretar um espaço de não direito, isto é, imune a qualquer regulação estatal.

$\mathrm{O}$ segundo aspecto se refere à forma com que as normas constitucionais incIdem sobre as relações particulares, isto é, se e em que medida as normas constitucionais necessitam da atuação do legislador para incidir nas relações entre particulares.

São estas as investigações a serem realizadas no presente trabalho.

\section{PERDA DA CENTRALIDADE DO CÓDIGO CIVIL E A SUPREMACIA DA CONSTITUIÇÃO}

Pode-se afirmar que o Código Civil Brasileiro de 1916 foi concebido em contexto no qual prevalecia um ideário individualista e voluntarista, que encontrou no Código de Napoleão a sua grande expressão. ${ }^{1}$ Havia, sob o referido ideário, a pretensão de centralidade do código civil, encarado esse "como monumentos da ordem jurídica, destinados a perdurar". ${ }^{2}$ Tratava-se, assim, o código civil como algo perene ${ }^{3}$, destinado a ultrapassar gerações e a conferir estabilidade ao sistema jurídico.

Em decorrência disso, o direito civil passou a ser confundido com o próprio código respectivo, que "regulava as relaçôes entre as pessoas privadas, seu estado, sua capacidade, sua família e, principalmente, sua propriedade”. ${ }^{4}$ Havia, portanto,

1 TEPEDINO, Gustavo. Normas constitucionais e relações de Direito Civil na experiência brasileira. In: Temas de direito civil. Rio de Janeiro: Renovar, 2006, Tomo 2, p. 23.

2 SCHREIBER, Anderson. Direito civil e Constituição. In: Direito civil e Constituição. São Paulo: Atlas, 2013, p. 8.

3 SCHREIBER, Anderson. Direito civil e Constituição. In: Direito civil e Constituição. São Paulo: Atlas, 2013, p. 8.

4 BODIN DE MORAES, Maria Celina. A caminho de um direito civil-constitucional. In: $\mathrm{Na}$ medida da pessoa humana. Rio de Janeiro: Renovar, 2010, p. 4. 
uma aspiração de completude do código ${ }^{5}$, cuja disciplina teria o condão de abarcar a totalidade das relações privadas.

Completude e perenidade do código foram reflexo de uma época em que se exigia segurança, refletida essa na previsibilidade das consequências do comportamento dos sujeitos, conforme sustenta Maria Celina Bodin de Moraes:

O sentido de segurança [...] surgiu das estruturas profundas da sociedade. A exigência de estabilidade, ou de previsibilidade, quanto aos comportamentos dos sujeitos passou a ser o pressuposto intrínseco das relações jurídicas, na medida em que a burguesia francesa, vitoriosa na Grande Revolução, se tornou a nova classe dirigente, portadora da tábua de valores na qual toda a sociedade foi chamada a se reconhecer. $\mathrm{O}$ 'mundo da segurança' é, portanto, o 'mundo dos códigos', que consubstanciam, em ordenada sequência de artigos, os valores do liberalismo do século XIX. ${ }^{6}$

Logo, se o que se objetivava era estabilidade, previsibilidade e permanência do código, ele estaria, assim, depurado de conteúdo ideológico, sobrevivendo incólume, pois, às naturais vicissitudes da sociedade, em especial “às revoluçôes políticas e às diversas ideologias"?

Consequência disso era a nítida separação dos campos de incidência do código civil e da constituição. Enquanto aquele se destinaria à regulação das relações privadas, a constituição vincularia o legislador ordinário, mormente no que se refere à concepção da estrutura do Estado. ${ }^{8}$ Em virtude de tal separação no âmbito de aplicação de ambos os diplomas, não se cogitava de uma norma hierarquicamente superior ao código civil no que tange ao campo de incidência desse. Tanto é assim que eventuais lacunas tinham que ser resolvidas dentro do próprio sistema, isto é, lançando-se mão de instrumentos previstos no âmbito do próprio direito privado. É daí a lógica que inspirou a tímida possibilidade de utilização dos princípios constitucionais pelo intérprete ${ }^{9}$, o que se reflete no art. $4^{\mathrm{o}^{10}} \mathrm{da}$ Lei

5 BODIN DE MORAES, Maria Celina. Constituição e direito civil: tendências. In: Na medida da pessoa humana. Rio de Janeiro: Renovar, 2010, p. 34.

6 BODIN DE MORAES, Maria Celina. Constituição e direito civil: tendências. In: Na medida da pessoa humana. Rio de Janeiro: Renovar, 2010, p. 34.

7 SCHREIBER, Anderson. Direito civil e Constituição. In: Direito civil e Constituição. São Paulo: Atlas, 2013, p. 8.

8 TEPEDINO, Gustavo. Normas constitucionais e relações de Direito Civil na experiência brasileira. In: Temas de direito civil. Rio de Janeiro: Renovar, 2006, Tomo 2, p. 24.

9 TEPEDINO, Gustavo. Normas constitucionais e relações de Direito Civil na experiência brasileira. In: Temas de direito civil. Rio de Janeiro: Renovar, 2006, Tomo 2, p. 24.

10 Art. $4^{\circ}$ Quando a lei for omissa, o juiz decidirá o caso de acordo com a analogia, os costumes e os princípios gerais de direito. 
de Introdução às Normas do Direito Brasileiro (DL 4657/42), no sentido de que a omissão na lei deve ser resolvida mediante a analogia, os costumes e os princípios gerais de direito.

Não se verificava, assim, a influência da constituição na interpretação do direito civil. Ela era vista como tendo conteúdo meramente programático, sendo considerada simples carta política, isto é, corporificava meras tendências apontadas pelo constituinte, ignorando-se, pois, a força normativa dos dispositivos do ápice do sistema jurídico. ${ }^{11}$ Tal prática subvertia por completo a lógica, na medida em que tornava a aplicação da norma situada no ápice do sistema algo meramente subsidiário, por ocasião da inexistência "de norma ordinária específica e após terem sido frustradas as tentativas, pelo intérprete, de fazer uso da analogia e da regra consuetudinária”. ${ }^{12}$

Pretendia-se, assim, sob o ideário então vigente, conferir a segurança jurídica proporcionada por um conjunto de normas reunidos em um código com pretensões de completude, de modo a prever, com clareza, as consequências dos atos das partes. Seria supostamente garantida, dessa maneira, a realização das atividades privadas de forma mais segura, em razão da previsibilidade e imutabilidade das normas insculpidas no código civil. ${ }^{13}$

Ocorre que por ocasião do final do século XIX e início do século XX, começaram a emergir na Europa a industrialização e a consequente emergência dos conflitos sociais daí decorrentes, mormente se for considerada a complexificação da sociedade na referida época. Dessa forma, o liberalismo e o voluntarismo, que até então prevaleciam, não mais conseguiram dar conta de tais conflitos, passando a ser necessária a intervenção do Estado legislador no sentido de discipliná-los. ${ }^{14}$

Essa realidade se refletiu no Brasil. Ato contínuo, foi iniciada a proliferação de produção legislativa extracodificada, a fim de regular as situações não previstas pelo código. Em um primeiro momento, tal legislação extravagante pretendia ser excepcional, episódica. Entretanto, com o passar do tempo, tal corpo de leis extracodificadas se tornou tão expressivo que já não mais foi possível considerar o

11 BODIN DE MORAES, Maria Celina. A caminho de um direito civil-constitucional. In: $\mathrm{Na}$ medida da pessoa humana. Rio de Janeiro: Renovar, 2010, p. 12-13.

12 TEPEDINO, Gustavo. Normas constitucionais e relações de Direito Civil na experiência brasileira. In: Temas de direito civil. Rio de Janeiro: Renovar, 2006, Tomo 2, p. 25.

13 TEPEDINO, Gustavo. Normas constitucionais e relações de Direito Civil na experiência brasileira. In: Temas de direito civil. Rio de Janeiro: Renovar, 2006, Tomo 2, p. 25.

14 TEPEDINO, Gustavo. Normas constitucionais e relações de Direito Civil na experiência brasileira. In: Temas de direito civil. Rio de Janeiro: Renovar, 2006, Tomo 2, p. 26. 
código civil como o centro do sistema do direito privado. Assim, o referido código passou a ser considerado expressão do direito comum, a ser aplicável aos negócios jurídicos em geral, enquanto ao seu lado passaram a vigorar as leis extravagantes, destinadas a regular os novos institutos surgidos com a evolução econômica. Tais são as leis especiais, que passaram a regular relações não contempladas no código, mas sem "qualquer caráter emergencial ou conjuntural". ${ }^{15}$

Ainda no contexto da necessidade de fazer frente às novas demandas sociais advindas com o progresso econômico e o desenvolvimento industrial, começaram a surgir Constituições com maior cunho interventivo nas questôes sociais. Percebeu-se que não só o Estado se constituía em ameaça aos particulares, mas as ameaças e abusos poderiam partir de outro particular, o que levou à necessidade de uma ação estatal mais efetiva. ${ }^{16}$ A Constituição de Weimar inaugura essa fase, em 1919. Tal constituição, ao lado da formação da estrutura do Estado, pretendeu regular diversas outras matérias, inclusive atinentes às relações jurídico-privadas. Porém, a despeito dessa pretensão, referida constituição ainda tinha eficácia jurídica mais restrita, na medida em que, em muitos casos, remetia para o legislador ordinário a competência para regulamentar determinadas matérias nela previstas. Em razão disso, a constituição de Weimar, embora sendo considerada um passo adiante no que se refere ao espectro de matérias constitucionalmente disciplinadas, ainda possuía uma baixa normatividade, em virtude da deferência prestada, em muitas ocasiôes, ao legislador ordinário. ${ }^{17}$ Com isso, ainda não foi aí a abertura de um campo fértil para a colocação da constituição, de forma eficaz, no ápice de um ordenamento jurídico.

Somente após a segunda grande guerra é que o panorama começou a se modificar. Muitas das constituiçôes que lhe foram posteriores já possuíam, além da pretensão de regulamentar questôes atinentes às relaçôes sociais, um grau maior de força jurídica, dotada de normas com maior vocação para a produção de efeitos

15 TEPEDINO, Gustavo. Normas constitucionais e relações de Direito Civil na experiência brasileira. In: Temas de direito civil. Rio de Janeiro: Renovar, 2006, Tomo 2, p. 27.

16 Uma das principais ameaças de violação de direitos de particulares por outros particulares se dá no campo do trabalho subordinado, a reclamar uma maior intervenção estatal. Segundo Maria Celina Bodin de Moraes, "A evolução do direito civil também se explica como um efeito da influência de grandes correntes do pensamento, em particular da marcada tendência para uma justiça social em maior proporção, decorrente, principalmente, do alastramento do trabalho subordinado." (BODIN DE MORAES, Maria Celina. A caminho de um direito civil-constitucional. In: Na medida da pessoa humana. Rio de Janeiro: Renovar, 2010, p. 6).

17 RIBEIRO, Joaquim de Sousa. Constitucionalização do direito civil. In: Boletim da Faculdade de Direito da Universidade de Coimbra, v. 74, p. 729-755, 1998, p. 731-732. 
concretos e diretos nas relações sociais. ${ }^{18}$ Nesse momento, pois, é que se pavimentou o caminho para que as constituiçóes, então, alçassem ao ápice do ordenamento jurídico com efetiva força normativa. São exemplos de constituições com estas características a Constituição Italiana de $1948^{19}$, a Constituição da Alemanha de 1949, a Constituição Portuguesa de 1976 e a Constituição Brasileira de 1988.

Nota-se, assim, uma situação de muito maior complexidade normativa do que aquela verificada no início do século XX, por ocasião da instituição do código civil de 1916. Afinal, naquela época, tinha-se esse como o diploma que, por excelência, regulava as relações privadas, com as já citadas pretensas neutralidade, completude e perenidade. Já nos tempos atuais, além do código civil, tem-se uma pletora de leis extravagantes atinentes ao direito civil. Além disso, supera-se a ideia de outrora segundo a qual a constituição era considerada, apenas, uma carta política, passando-se à fase em que nela se reconhece uma efetiva força normativa.

Diante de tal complexidade normativa, foi preciso estabelecer a interconexão lógica entre código civil, as leis extravagantes e a constituição, ou seja, uma coexistência coerente. E isto se deu, sobretudo, pela emanação, da constituição, dos princípios e valores que vão se espraiar e informar a totalidade do ordenamento, incluindo-se aí o direito civil. É o que sustenta Gustavo Tepedino:

Propriedade, empresa, família, relações contratuais tornam-se institutos funcionalizados à realização dos valores constitucionais, em especial da dignidade da pessoa humana, não mais havendo setores imunes a tal incidência axiológica, espécies de zonas francas para a atuação da autonomia privada. A autonomia privada deixa de configurar um valor em si mesma, e será merecedora de tutela somente se representar, em concreto, a realização de um valor constitucional. ${ }^{20}$

Portanto, o direito civil, como todos os demais campos do direito, não está, de modo algum, imune à incidência dos princípios e valores emanados da Constituição, sendo, assim, por eles conformado. Cai por terra, por conseguinte, a tradicional noção de que o direito civil seria algo neutro e atemporal. ${ }^{21}$ Vale, nesse sentido, trazer à baila os ensinamentos de António Manuel Hespanha, para quem:

18 RIBEIRO, Joaquim de Sousa. Constitucionalização do direito civil. In: Boletim da Faculdade de Direito da Universidade de Coimbra, v. 74, p. 729-755, 1998, p. 732.

19 TEPEDINO, Gustavo. Normas constitucionais e relações de Direito Civil na experiência brasileira. In: Temas de direito civil. Rio de Janeiro: Renovar, 2006, Tomo 2, p. 29.

20 TEPEDINO, Gustavo. Normas constitucionais e direito civil na construção unitária do ordenamento. In: Temas de direito civil. Rio de Janeiro: Renovar, 2009, Tomo 3, p. 5-6.

21 SCHREIBER, Anderson. Direito civil e Constituição. In: Direito civil e Constituição. São Paulo: Atlas, 2013, p. 8. 
[...] a missão histórica do direito é antes a de problematizar o pressuposto implícito e acrítico das disciplinas dogmáticas, ou seja, o de que o direito dos nossos dias é o racional, o necessário, o definitivo. A história do direito realiza esta missão sublinhando que o direito existe sempre 'em sociedade' (situado, localizado) e que, seja qual for o modelo usado para descrever as suas relações com os contextos sociais (simbólicos, políticos, econômicos, etc.), as soluções jurídicas são sempre contingentes em relação a um dado envolvimento (ou ambiente). São, neste sentido, sempre locais. ${ }^{22}$

Logo, nota-se que o direito só o é no contexto em que inserido. Ou melhor: o direito nunca é, mas sim, está. Repulsiva à ideia de historicidade, contextualização e pertencimento será a tradicional ideia de neutralidade e perenidade que se tinha, outrora, do direito civil. E quem determina essa contextualização é a Constituição. $\mathrm{O}$ direito somente está na medida em que sofre a incidência da Constituição.

Daí surge a noção de direito civil constitucional, sendo esse a expressão da convicção de que não existe, na realidade, um direito neutro e atemporal. Aliás, a própria invocação da neutralidade de outrora refletia a máxima expressão do individualismo de então, de modo a apartar da regulamentação estatal as relações negociais estabelecidas entre os particulares. Logo, a referida "neutralidade", de neutralidade, nada tinha. ${ }^{23}$

\section{INEXISTÊNCIA DE SETORES IMUNES À INCIDÊNCIA CONSTITUCIONAL: REJEIÇÃO DE ESPAÇOS DE NÃO DIREITO}

O fato de as constituições serem alçadas ao ápice do ordenamento com efetiva força normativa apenas acentuou a tendência de desconsideração do código civil como diploma central do direito privado. No caso brasileiro, por exemplo, em razão da abrangência da constituição e da real eficácia das normas definidoras de direitos, muitas leis especiais foram editadas ao longo dos anos, tais como o Código de Defesa do Consumidor, o Estatuto da Criança e do Adolescente, o Estatuto do Idoso e o Estatuto da Pessoa com Deficiência. ${ }^{24}$ Importante notar que as leis mencionadas espelham valores e princípios emanados da Constituição, a realçar a centralidade que essa ocupa no ordenamento.

22 HESPANHA, António Manuel. Cultura jurídica europeia: síntese de um milênio. Coimbra: Almedina, 2012, p. 13.

23 SCHREIBER, Anderson. Direito civil e Constituição. In: Direito civil e Constituição. São Paulo: Atlas, 2013, p. 8.

24 TEPEDINO, Gustavo. Normas constitucionais e relações de Direito Civil na experiência brasileira. In: Temas de direito civil. Rio de Janeiro: Renovar, 2006, Tomo 2, p. 30. 
E vale ressaltar a observação de Gustavo Tepedino, no que tange à insistência de alguns em se considerar o código como o elemento central do ordenamento, referindo-se à errônea interpretação do art. $4^{0}$ da Lei de Introdução às Normas do Direito Brasileiro:

Tal alteração metodológica implica a superação de outro grande equívoco, já acima acenado, em que incorrem os operadores do direito e os civilistas em particular: a consideração dos princípios constitucionais como meros princípios gerais de direito, não como normas jurídicas aplicáveis aos casos concretos. O Código Civil seria o verdadeiro estatuto constitucional do direito privado, de tal modo que os princípios constitucionais, além de funcionarem como limite ao legislador ordinário, se constituiriam em princípios gerais do direito, utilizados de maneira apenas indireta pelo intérprete.

$[\ldots]$

Daqui decorre que a consideração de tais normas como princípios gerais de direito significaria adotá-las, nas relações privadas, somente na hipótese de inexistir lei infraconstitucional prevista especificamente para o caso concreto, ausente ainda a possibilidade de analogia e sendo impossível recorrer aos costumes, nos termos do art. $4^{\mathrm{o}}$, da Lei de Introdução ao Código Civil. ${ }^{25}$

Pois bem: se a constituição funciona como o centro do ordenamento, estando em seu ápice, funcionará ela como o polo irradiador de princípios e valores que conformarão o ordenamento como um todo. E isso acarreta algumas consequências. A primeira delas é o papel da constituição como um elemento unificador do sistema interpretativo. Desse modo, todas as normas devem ser interpretadas à luz da constituição. Sendo assim, não mais são verificados sistemas setoriais (microssistemas), voltados para si próprio, sem comunicação com a constituição ou com os outros diplomas normativos. Na realidade, em havendo um diploma normativo na centralidade do ordenamento, todos os conjuntos de normas acabam sendo dirigidos por um liame em comum, a sistematizar o ordenamento. ${ }^{26}$

Em razão da referida sistematização, sendo a constituição o liame que a produz, as antinomias devem ser resolvidas à luz dos princípios e valores constitucionais. ${ }^{27}$ Logo, os dispositivos contidos nas leis setoriais devem ser interpretados à luz

25 TEPEDINO, Gustavo. As relaçôes de consumo e a nova teoria contratual, p. 6. Disponível em: <http://www.egov. ufsc.br/portal/sites/default/files/anexos/8788-8787-1-PB.pdf>. Acesso em: 04 out. 2017.

26 TEPEDINO, Gustavo. Normas constitucionais e relaçôes de Direito Civil na experiência brasileira. In: Temas de direito civil. Rio de Janeiro: Renovar, 2006, Tomo 2, p. 33.

27 TEPEDINO, Gustavo. Normas constitucionais e relaçôes de Direito Civil na experiência brasileira. In: Temas de direito civil. Rio de Janeiro: Renovar, 2006, Tomo 2, p. 33. 
da Constituição, de modo que eventuais antinomias sejam superadas a partir da interpretação à luz daqueles princípios e valores.

Já em um contexto no qual se rejeita a Constituição como o polo irradiador de princípios e valores para todo o ordenamento, a existência de nichos legais, dotados de uma lógica própria e interna, seria a decorrência natural. Recorrendo-se à analogia, tais nichos equivaleriam às placas tectônicas, que ora se chocam e se friccionam, ora se afastam, fazendo surgir fendas. $\mathrm{Na}$ primeira situação, teríamos as antinomias e as redundâncias que, em um contexto desprovido de um liame comum, devem ser resolvidas por meio de instrumentos que lhe são de mesma hierarquia - por exemplo, conforme preceitua o art. $4^{\circ}$ da LINDB -, já que, como visto, não haveria normas superiores que se espraiassem para as normas em contradição. Por outro lado, no caso dos afastamentos, ocorreria o surgimento de espaços de não direito.

Sendo assim, os espaços de não direito, somente existentes sob ambiente de rejeição da constituição como o diploma ocupante do seu cume, seriam aquelas fendas provocadas pela omissão do legislador infraconstitucional em disciplinar determinada matéria. Tal omissão, no caso de espaço de não direito, seria aquela deliberada, por entender o legislador que determinada matéria não merecia ser disciplinada. E isso poderia se dar em duas situaçôes:

a) Com o entendimento por parte do legislador de que determinada matéria não possuiria relevância social merecedora de disciplina.

b) Com o entendimento por parte do legislador de que sua intervenção em determinada matéria seria inconveniente.

Com relação ao primeiro caso, podemos citar aquelas situações aparentemente prosaicas e desimportantes, tais como a que rege o processo de escolha da cor de uma camisa ou do sabor de um sorvete a ser comprado. O legislador, aqui, não entendeu ser necessária a imposição, via legal, de tal ou qual cor ou tal ou qual sabor.

Porém, em se entendendo de forma diferente, ou seja, a se partilhar da ideia de existência da centralidade da Constituição, no mínimo o processo de escolha da cor da roupa ou do sabor do sorvete será ditado pela liberdade. Nesse espaço de omissão do legislador infraconstitucional incidirão as normas constitucionais.

Com relação à segunda situação mencionada acima, há casos em que, claramente, por opção política, o legislador deixa de regulamentar determinada matéria. Porém, aqui, não por entendê-la desimportante, mas sim por entender que a intervenção dele, legislador, é inconveniente. 
Isto se dá, por exemplo, nos casos em que, vigorando exacerbado ideário liberal, rejeita-se quase que por completo a intervenção estatal. Quanto a isto, situação concreta é o movimento que vem sendo construído no Brasil de estabelecimento de uma acentuada divisão entre contratos civis e empresariais, estes últimos imunes "a intervenções jurídicas e a todas aquelas noveis construções inspiradas na tábua axiológica da norma fundamental da ordem jurídica brasileira". ${ }^{28}$

Para além da manifesta discordância em relação à metodologia civil constitucional, o posicionamento daqueles que sustentam uma espécie de imunidade dos contratos empresariais parece incorrer em insanável ilogicidade. Afinal, uma coisa é partilhar do posicionamento segundo o qual a constituição não ocupa o cume do ordenamento, de modo que, por consequência, não será ela a incidir nos contratos empresariais. Repetindo, tal posicionamento, em que pese contrariar a metodologia civil constitucional, guarda uma lógica interna. Parte-se de uma premissa equivocada, mas da qual, necessariamente, pela lógica, se chega à conclusão segundo a qual as normas e princípios constitucionais não se aplicariam aos contratos empresariais. Chegou-se, nesse exemplo, à conclusão equivocada pelo fato de as premissas terem sido, igualmente, equivocadas. Mas a lógica interna do raciocínio é perfeita. Porém, reconhecer a centralidade da constituição, mas reconhecer a sua incidência somente em parte do ordenamento é, indubitavelmente, um raciocínio que não se sustenta em nenhuma circunstância, por padecer de ilogicidade interna. Ou seja, das premissas das quais se parte, não há hipótese de se chegar à conclusão preconizada. Isto porque, se a constituição ocupa a centralidade do ordenamento, os princípios e valores que dela irradiam irrigam a totalidade do ordenamento, não devendo haver, portanto, zonas de sombra, quanto mais se estabelecidas pelo legislador ordinário. Entender diversamente, isto é, entender no sentido de que há áreas de sombra, é inverter a lógica do sistema, com o legislador infraconstitucional condicionando e conformando a incidência das normas constitucionais.

Não se pode confundir as situações acima com aquelas nas quais o legislador infraconstitucional não legisla quer por esquecimento, quer por não ter previsto determinada matéria. Aí, não se está falando de espaço de não direito, mas sim de uma lacuna. Nesses casos, em se entendendo que a constituição não ocupa o papel central do ordenamento, a própria legislação indica os instrumentos por meio dos quais tais lacunas serão superadas - como aqueles previstos no art. $4^{\circ}$ da LINDB.

28 SCHREIBER, Anderson; KONDER, Carlos Nelson. Uma agenda para o direito civil constitucional. IBDCivil, v. 10, p. 21, 2016. Disponível em: <https://www.ibdcivil.org.br/image/ data/revista/volume10/rbdcivil_vol_10_02_doutrina-nacional_uma-agenda.pdf $>$. Acesso em: 04 out. 2017. 
Sendo assim, o simples fato de se entender necessário lançar mão dos critérios de superação de lacunas em determinada matéria já as afasta, automaticamente, dos espaços de não direito.

Entretanto, em se entendendo que a Constituição ocupa a centralidade do ordenamento, as lacunas da legislação devem ser supridas por meio daquilo que indica a constituição.

Mas a incidência da constituição não se resume às situações de lacuna. Afinal, mesmo quando há uma previsão legal específica para a hipótese, as normas constitucionais incIdem sobre o caso. Daí a afirmação de Gustavo Tepedino:

A este respeito, deve-se observar que o direito civil assistiu ao deslocamento de seus princípios fundamentais do Código Civil para a Constituição. Tal realidade, reduzida por muitos a fenômeno de técnica legislativa, ou mesmo à mera atecnia, revela profunda transformação dogmática, em que a autonomia privada passa a ser remodelada por valores não patrimoniais, de cunho existencial, inseridos na própria noção de ordem pública. Propriedade, empresa, família, relaçōes contratuais tornam-se institutos funcionalizados à realização dos valores constitucionais, em especial da dignidade da pessoa humana, não mais havendo setores imunes a tal incidência axiológica, espécies de zonas francas para a autonomia privada. A autonomia privada deixa de configurar um valor em si mesma, e será merecedora de tutela somente se representar, em concreto, a realização de um valor constitucional. ${ }^{29}$

Há uma explicação racional para a supremacia axiológica da constituição. $\mathrm{Na}$ realidade, ela exprime os consensos mínimos da sociedade. A constituição, especialmente aquela que estabelece o Estado Democrático de Direito e é oriunda de um processo constituinte originário, como é a de 1988, é o elemento fundador da racionalidade social e política ${ }^{30}$, refletindo a concepção de sociedade da época em que editada.

E essa inauguração, por uma constituição, de um novo estado de coisas se dá de maneira bastante evidente na medida em que a nossa constituição sucedeu constituição autoritária. Então, dizer que a Constituição de 1988 funda uma racionalidade social e política talvez se torne mais fácil, em virtude do regime autoritário anterior. Ocorre que essa afirmação sempre se justifica, mesmo que seja um regime democrático superando um outro período democrático. Isto porque deve-se ler a constituição como a fundação de uma racionalidade adequada ao momento. Nesse sentido, sustenta Pietro Perlingieri:

29 TEPEDINO, Gustavo. Normas constitucionais e direito civil na construção unitária do ordenamento. In: Temas de direito civil. Rio de Janeiro: Renovar, 2009, Tomo 3, p. 5.

30 STRECK, Lênio. Hermenêutica jurídica e $(m)$ crise: uma exploração hermenêutica da construção do direito. Porto Alegre: Livraria do Advogado, 1999, p. 214-215. 
Dever do jurista, e especialmente do civilista, é 'reler' todo o sistema do código e das leis especiais à luz dos princípios constitucionais [...], de forma a individuar uma nova ordem científica que não freie a aplicação do direito e seja mais aderente às escolhas de fundo da sociedade contemporânea. ${ }^{31}$

A racionalidade instaurada pela constituição é a única adequada para aquele momento histórico. Ainda que pudessem ocorrer outros pactos possíveis, a constituição representa o pacto vigente. Dessa forma, não há "pactos” vigentes, mas sim um único "pacto" vigente ${ }^{32}$, que deve ter, portanto, a máxima eficácia. Ilógico, então, enfraquecer a constituição, sob pena de se conceber a efetivação de algo que não corresponde ao pacto nela corporificado. Daí a constituição como ocupante do ápice do ordenamento.

E a consequência lógica da colocação da constituição na posição de cume do ordenamento, com o fortalecimento de sua normatividade, é a incidência de seus princípios e valores por todo o ordenamento, devendo as leis que lhe estão abaixo ser interpretadas à luz daqueles. Confere-se, assim, unidade e completude ao sistema. Mais uma vez, recorre-se à lição de Gustavo Tepedino:

[...] como antes demonstrado, as normas constitucionais afiguram-se parte integrante da dogmática do direito civil, remodelando e revitalizando os seus institutos, em torno de sua força reunificadora do sistema. Se assim não fosse, o ordenamento restaria fragmentado, decompondo-se o sistema por força da pluralidade de núcleos legislativos que substitui, no curso do tempo, o sistema monolítico da codificação oitocentista. ${ }^{33}$

Como se percebe do trecho transcrito, a constituição preenche todas as "fendas legislativas", tornando unitário o ordenamento. Sendo assim, não se concebe a existência de espaços desprovidos de incidência da constituição. Daí é que Pietro Perlingieri sustenta a relevância jurídica de todo e qualquer fato concreto. Nesse sentido:

O fato concreto é sempre juridicamente relevante; não sempre, todavia, a norma lhe atribui consequências jurídicas tangíveis, que podem ser individuadas de modo específico e determinado como o nascimento, a aquisição, a extinção, a modificação de uma de uma situação subjetiva [...].

[...]

Fato juridicamente relevante não é somente aquele produtor de consequências jurídicas que podem ser bem individuadas, mas qualquer fato, enquanto expressão

31 PERLINGIERI, Pietro. O direito civil na legalidade constitucional. Rio de Janeiro: Renovar, 2008, p. 137.

32 HESPANHA, António Manuel. Cultura jurídica europeia: síntese de um milênio. Coimbra: Almedina, 2012, p. 13.

33 TEPEDINO, Gustavo. Normas constitucionais e direito civil na construção unitária do ordenamento. In: Temas de direito civil. Rio de Janeiro: Renovar, 2009, Tomo 3, p. 8. 
Aplicação direta $x$ indireta das normas constitucionais rejeição de... | Bruno Terra de Moraes

positiva ou negativa (fato ilícito) de valores ou de princípios presentes no ordenamento. Não existe fato que não tenha uma valoração expressa ou implícita no âmbito do ordenamento. ${ }^{34}$

O raciocínio de Pietro Perlingieri é absolutamente lógico. Afinal:

a) a constituição se localiza no ápice do ordenamento;

b) ela tem força normativa;

c) seus princípios e valores são aplicados à totalidade do ordenamento;

d) ela confere unidade ao sistema, impedindo que este se apresente de forma fragmentada e entender de forma diferente contrariaria a própria noção de sistema;

e) se há unidade do ordenamento, não há "fendas" legislativas;

f) se não há "fendas" legislativas, todos os fatos terão uma valoração, ainda que não expressa, no ordenamento.

Inconcebíveis, portanto, os espaços de não direito. Mesmo fatos corriqueiros, tais como a escolha da cor de uma camisa ou do sabor de um sorvete - exemplos já citados anteriormente - configuram-se emanações de princípios e valores constitucionais, como, por exemplo, a liberdade.

E mesmo naquelas situações em que se pretende conferir um maior espaço à autonomia privada, isto é, um maior espaço a que os particulares regulem seus interesses, o que aí ocorre é a conferência de tal espaço pelo próprio ordenamento. Vale dizer: não é um espaço imune à incidência do direito, mas sim um espaço no qual o próprio direito confere aos particulares um campo maior de ação. Isto não impede que, extrapolado esse campo de ação conferido pelo ordenamento, as normas constitucionais sejam invocadas pela parte eventualmente prejudicada. Assim, é a própria constituição que confere, em determinados campos, um maior espaço de autorregulamentação aos particulares, maior espaço este fundado em seus próprios princípios e valores, tais como a Liberdade, prevista no seu art. $5^{\circ}$, caput, e a Livre Iniciativa, prevista no seu art. 170, admitindo-se a invocação de eventuais princípios e valores contrapostos no caso concreto.

Não há, pois, fatos irrelevantes para o direito.

Assentado o fato de que a constituição ocupa o ápice do ordenamento, espraiando seus princípios e valores para a totalidade do ordenamento e impedindo a existência de espaços de não direito, resta saber se suas normas se aplicam direta ou indiretamente às relações privadas. É o que se analisará adiante.

34 PERLINGIERI, Pietro. Perfis do direito civil. 3. ed. Rio de Janeiro: Renovar, 2002, p. 90. 


\section{APLICAÇÃO DIRETA X INDIRETA DAS NORMAS CONSTITUCIONAIS ÀS RELAÇÕES PRIVADAS}

Como se viu, a constituição incide sobre todo o ordenamento, não permitindo que, no espaço compreendido entre as diferentes leis setoriais, sejam verificados espaços de não direito. Diante dessa premissa, afigura-se claro, já de início, esse campo de aplicabilidade imediata da constituição, isto é, quando se verifica a ausência de norma infraconstitucional reguladora das relações em questão. Ou seja, considerando-se a constituição como autêntica norma, ilógico é entender que ela somente incidiria mediante a edição de uma norma infraconstitucional. ${ }^{35}$ Pensar o contrário seria ferir de morte a normatividade da constituição. Isto porque, em última análise, quem definiria o grau de normatividade da constituição seria o legislador ordinário, isto é, as normas constitucionais somente seriam aplicadas por intermédio de lei editada pelo próprio legislador. Tal situação não condiz com a posição de supremacia da constituição.

Logo, a partir das premissas até aqui adotadas, pode-se entender evidente que a constituição se aplica diretamente aos fatos jurídicos que deixaram de ser contemplados na legislação ordinária. Resta analisar, contudo, os casos em que o legislador infraconstitucional, de fato, editou normas disciplinadoras da matéria. Logo, se determinada relação jurídica é abarcada por legislação infraconstitucional, deve-se investigar como se dará a incidência, nesses casos, da constituição. Vale dizer: deve ser verificado se sua aplicação será direta (imediata) ou indireta (mediata)?

E a fim de estabelecer as bases para a resposta à indagação acima, devem ser retomadas algumas ideias já expostas no presente trabalho, mormente no que se refere à visão tradicional da posição da constituição no ordenamento. Lembre-se de que em um contexto no qual se pretendia o direito civil como algo permanente, neutro e completo, pouquíssimo espaço se abria para a incidência da constituição nas relações civis. E essa afirmação decorre da própria lógica do referido ideário: se o direito civil é completo, regula de forma suficiente as relaçóes por ele tratadas, não sendo necessário recorrer a diplomas outros.

Decorre daí a ideia de que a constituição constituiria um simples limite em relação às normas ordinárias. Desta forma, se não afrontassem interesses constitucionalmente protegidos, as normas ordinárias ganhariam vida autônoma, a incidir sobre as relações jurídicas independentemente da constituição. Com isso, somente em situações de falta de legislação específica é que a norma constitucional incidiria,

35 PERLINGIERI, Pietro. Perfis do direito civil. 3. ed. Rio de Janeiro: Renovar, 2002, p. 11. 
ou seja, de forma meramente residual. ${ }^{36}$ Certamente que tal concepção torna rarefeita a normatividade da Constituição.

E no que tange à eficácia indireta, Daniel Sarmento, tratando especificamente dos direitos fundamentais, apresenta algumas de suas principais características daquela ao afirmar que "cabe antes de tudo ao legislador privado a tarefa de mediar a aplicação dos direitos fundamentais sobre os particulares, estabelecendo uma disciplina nas relações privadas que se refere compatíveis com os valores constitucionais" ${ }^{37}$

Note-se do trecho acima que, para os adeptos da eficácia indireta, mesmo no que se refere aos direitos fundamentais, haveria a necessidade de uma participação do legislador ordinário a fim de possibilitar a fruição dos referidos direitos.

Deve ser analisada, ainda, a tese de que, além de ser limite, a constituição seria, também, um parâmetro interpretativo, isto é, seria "além de [...] um limite à norma ordinária, uma expressão de princípios jurídicos gerais a serem utilizados somente em sede de interpretação de enunciados normativos ordinários" . ${ }^{38}$ Observe-se que isto já representa algum avanço em relação à tese de que a constituição funcionaria, apenas, como um limite ao legislador ordinário. Contudo, tal avanço é, ainda, muito tímido, já que coloca a constituição em uma posição meramente passiva. Deve-se deixar assentado que conferir alto grau de normatividade à constituição é incompatível com a ideia de que suas normas são, apenas, uma regra hermenêutica, já que não são utilizadas plenamente "as potencialidades das normas constitucionais". 39

No direito estrangeiro, mais especificamente em Portugal, também são encontradas vozes a advogar a aplicação indireta da constituição às relações privadas. Uma das mais qualificadas nesse sentido é a de Carlos Alberto da Mota Pinto, para quem:

Parece conveniente e suscetível de conduzir a resultados mais razoáveis que a aplicação das normas constitucionais e actividades privadas se faça em primeira linha com referência a instrumentos e regras próprias do direito civil. Assim se chama a atenção para a necessidade de atenuações à plena afirmação de um ou outro princípio constitucional, isoladamente considerado, por força de princípios fundamentais de direito

36 PERlingIERI, Pietro. Perfis do direito civil. 3. ed. Rio de Janeiro: Renovar, 2002, p. 10.

37 SARMENTO, Daniel. A vinculação dos particulares aos direitos fundamentais no direito comparado e no Brasil. In: BARROSO, Luis Roberto (Org.). A reconstrução democrática do direito público no Brasil. Rio de Janeiro: Renovar, 2007, p. 308.

38 PERLINGIERI, Pietro. Perfis do direito civil. 3. ed. Rio de Janeiro: Renovar, 2002, p. 10.

39 PERLINGIERI, Pietro. Perfis do direito civil. 3. ed. Rio de Janeiro: Renovar, 2002, p. 12. 
privado, também eles consagrados na Constituição (ou, pelo menos, conformes a ela): por exemplo, o princípio da igualdade do cidadão não pode prevalecer, antes tem que ceder, sobre a liberdade contratual $[\ldots] .{ }^{40}$

Nota-se do trecho acima que as normas constitucionais, para produzirem melhores resultados segundo o referido autor, deverão ser remetidas a regras próprias do direito civil. Assim, as normas constitucionais conformariam a legislação infraconstitucional, mas não seriam diretamente aplicadas às relações jurídicas privadas. Para o referido autor, entender diversamente seria prejudicial, na medida em que os preceitos constitucionais seriam por demais genéricos, dificultando a invocação de uma pretensão com base neles. ${ }^{41}$

Diante disso, Carlos Alberto da Mota Pinto sustenta que:

A aplicação das normas constitucionais à atividade privada faz-se:

a) através de normas de direito privado que reproduzem o seu conteúdo [...];

b) através de cláusulas gerais e conceitos indeterminados, cujo conteúdo é preenchido com os valores constitucionalmente consagrados [...];

d) em casos absolutamente excepcionais, por não existir cláusula geral ou conceito indeterminado adequado, uma norma constitucional reconhecedora de um direito fundamental aplica-se independentemente de da mediação de uma regra de direito privado. $^{42}$

Note-se que Carlos Alberto da Mota Pinto, em que pese advogar a aplicabilidade indireta das normas constitucionais às relaçóes privadas, possui um posicionamento moderado com relação ao tema. Isto porque, admite, ainda que em situações excepcionais, a aplicabilidade direta de referidas normas, conforme se infere da alínea c), acima.

Já sustentando a incidência direta das normas constitucionais às relações privadas, encontra-se José Joaquim Gomes Canotilho, para quem:

Hoje, é a própria constituição a prescrever a aplicabilidade directa: as normas constitucionais além de serem de direito actual no sentido acabado de precisar, valem também como normas de aplicação directa. Assim, por exemplo, o art. 18\%/I da CRP [...] dispõe que "os preceitos constitucionais respeitantes aos direitos, liberdades e garantias são diretamente aplicáveis e vinculam as entidades públicas e privadas”. O que significa, em termos jurídico-constitucionais, aplicabilidade directa?

40 PINTO, Carlos Alberto da Mota. Teoria geral do direito civil. 4. ed. Coimbra: Coimbra Editora, 2012, p. 75.

41 PINTO, Carlos Alberto da Mota. Teoria geral do direito civil. 4. ed. Coimbra: Coimbra Editora, 2012, p. 76.

42 PINTO, Carlos Alberto da Mota. Teoria geral do direito civil. 4. ed. Coimbra: Coimbra Editora, 2012, p. 74-75. 
$[\ldots]$

Aplicabilidade directa significa, desde logo, nesta sede - direitos, liberdades e garantias - a rejeição da "ideia criacionista" conducente ao desprezo dos direitos fundamentais enquanto não forem positivados a nível legal. [...].

Aplicação directa não significa apenas que os direitos, liberdades e garantias se aplicam independentemente de intervenção legislativa [...]. Significa também que eles valem diretamente contra a lei, quando esta estabelece restriçốes em desconformidade com a constituição [...]. Em termos práticos, a aplicação directa dos direitos fundamentais implica ainda a inconstitucionalidade de todas as leis pré-constitucionais contrárias às normas da constituição consagradoras e garantidoras de direitos, liberdades e garantias ou direitos de natureza análoga [...]. Se se preferir, dir-se-á que a aplicação directa dos direitos, liberdades e garantias implica a inconstitucionalidade superveniente das normas pré-constitucionais em contradição com eles. ${ }^{43}$

Canotilho é claro no sentido de rejeitar a tese de que as normas constitucionais dependeriam de um veículo - a lei - para incidir no caso concreto. Portanto, a intervenção do legislador não é uma condicionante para que as normas constitucionais incidam sobre as relações jurídicas.

$\mathrm{O}$ referido autor aponta, ainda, que a incidência da norma constitucional também se dá de forma direta sobre a lei, na medida em que induz à inconstitucionalidade das normas que lhe são divergentes. E se assim o é, parece claro que incidirá também diretamente sobre a relação jurídica a ser considerada. A norma constitucional regula, assim, a relação jurídica concreta. Pegue-se o exemplo de relação jurídica abrangida por lei inconstitucional: note-se que, nesse caso, não há a necessidade de haver a declaração formal da inconstitucionalidade da lei reguladora para que a Constituição passe a regular, diretamente, aquela relação jurídica. Não: desde o momento em que tal relação se constituiu ela já se encontrava regulada pela norma constitucional. $\mathrm{O}$ que conduz à incidência da norma constitucional não é o momento em que se reconhece uma patologia da legislação. Na realidade, tal incidência é inerente ao ordenamento.

Mas deve ser observada, ainda, uma situação diversa, isto é, aquela na qual a norma infraconstitucional reguladora do caso concreto não é inconstitucional. Veja-se que na hipótese anterior, determinada relação jurídica estaria regulada por lei cuja inconstitucionalidade foi suscitada. Portanto, desde o seu nascedouro a relação jurídica estava regulada pela constituição, independentemente da declaração formal da inconstitucionalidade da lei. Mas e nos casos em que a questão da inconstitucionalidade da lei sequer se coloca, isto é, quando nem sequer se cogita da

43 CANOTILHO, José Joaquim Gomes. Direito constitucional e teoria da constituição. 7. ed. Coimbra: Almedina, 2003, p. 1178-1179. 
inconstitucionalidade da lei reguladora da relação jurídica concreta? Nesses casos, ainda assim subsistiria a incidência direta da Constituição sobre o caso concreto?

A resposta é positiva.

É importante deixar assentado que a participação do legislador ordinário é irrelevante para fins de se considerar se, no caso concreto, a aplicabilidade das normas constitucionais será direta ou indireta. Portanto, quer seja o legislador omisso, quer tenha instituído lei inconstitucional, quer tenha instituído lei constitucional, a aplicabilidade da constituição à relação jurídica se dará de maneira direta. A razão principal para isto é o fato de ser essa a única solução que confere o máximo possível de efetividade às normas constitucionais, não se permitindo que ao legislador seja viável, de alguma forma, manipular a normatividade da constituição. Pensar diferente, isto é, admitir que os atos do legislador ordinário influenciem na aplicabilidade das normas constitucionais é condicionar a eficácia da constituição ao legislador ordinário, e não o contrário, isto é, a eficácia da constituição condicionar o legislador ordinário. O legislador ordinário é que definiria em que termos a constituição incidiria sobre o caso concreto. Seria, assim, subverter a lógica, já que aquilo que está no ápice do ordenamento seria condicionado por quem lhe está abaixo.

A subversão acima apontada da lógica seria a própria negação do ordenamento jurídico como sendo, de fato, um ordenamento. Deve-se levar em consideração que a existência de um ordenamento leva em consideração o fato de que coexistem diversas normas, de diversos graus hierárquicos e de distintos campos de incidência. Tais diferentes normas devem coexistir de maneira harmônica, sob pena de se ter um amontoado disforme de diplomas legislativos, sem uma interconexão coerente. Daí a afirmação de Gustavo Tepedino:

Se o conceito de ordenamento pudesse se reduzir ao conjunto de normas de um mesmo nível hierárquico, poder-se-ia admiti-lo como um universo técnico homogêneo e fechado em si mesmo. Sendo, ao contrário, o ordenamento jurídico composto por uma pluralidade de fontes normativas, apresenta-se necessariamente como sistema heterogêneo e aberto; e, daí a sua complexidade que, só alcançará a unidade, caso seja assegurada a centralidade da Constituição, que contém a tábua de valores que caracterizam a identidade cultural da sociedade. ${ }^{44}$

Se é a constituição que faz com que o ordenamento jurídico seja entendido como tal, os valores e princípios dela emanados incIdem diretamente sobre a totalidade daquele. Entender diversamente ou seja, pela aplicabilidade meramente indireta, acarretaria as seguintes consequências:

44 TEPEDINO, Gustavo. Normas constitucionais e direito civil na construção unitária do ordenamento. In: Temas de direito civil. Rio de Janeiro: Renovar, 2009, Tomo 3, p. 9-10. 
Aplicação direta $x$ indireta das normas constitucionais rejeição de... | Bruno Terra de Moraes

a) em caso de omissão do legislador, a inaplicabilidade das normas constitucionais; e

b) em caso de atuação do legislador, a existência de um anteparo postado entre a Constituição e a relação jurídica, impedindo que as normas constitucionais cheguem à superfície.

Ambas as situações são inconcebíveis, já que o legislador ordinário, em ambos os casos, é que definiria o grau de força normativa da constituição.

E a aplicabilidade direta das normas constitucionais às relações privadas já foi reconhecida pelo Supremo Tribunal Federal. Exemplo disto pode ser encontrado na decisão prolatada no RE 201819/RJ ${ }^{45}$, que versa sobre situação na qual um

45 "EMENTA: SOCIEDADE CIVIL SEM FINS LUCRATIVOS. UNIÃO BRASILEIRA DE COMPOSITORES. EXCLUSÃO DE SÓCIO SEM GARANTIA DA AMPLA DEFESA E DO CONTRADITÓRIO. EFICÁCIA DOS DIREITOS FUNDAMENTAIS NAS RELAÇÕES PRIVADAS. RECURSO DESPROVIDO. I. EFICÁCIA DOS DIREITOS FUNDAMENTAIS NAS RELAÇÕES PRIVADAS. As violações a direitos fundamentais não ocorrem somente no âmbito das relações entre o cidadão e o Estado, mas igualmente nas relações travadas entre pessoas físicas e jurídicas de direito privado. Assim, os direitos fundamentais assegurados pela Constituição vinculam diretamente não apenas os poderes públicos, estando direcionados também à proteção dos particulares em face dos poderes privados. II. OS PRINCÍPIOS CONSTITUCIONAIS COMO LIMITES À AUTONOMIA PRIVADA DAS ASSOCIAÇŌES. A ordem jurídico-constitucional brasileira não conferiu a qualquer associação civil a possibilidade de agir à revelia dos princípios inscritos nas leis e, em especial, dos postulados que têm por fundamento direto o próprio texto da Constituição da República, notadamente em tema de proteção às liberdades e garantias fundamentais. $\mathrm{O}$ espaço de autonomia privada garantido pela Constituição às associações não está imune à incidência dos princípios constitucionais que asseguram o respeito aos direitos fundamentais de seus associados. A autonomia privada, que encontra claras limitações de ordem jurídica, não pode ser exercida em detrimento ou com desrespeito aos direitos e garantias de terceiros, especialmente aqueles positivados em sede constitucional, pois a autonomia da vontade não confere aos particulares, no domínio de sua incidência e atuação, o poder de transgredir ou de ignorar as restrições postas e definidas pela própria Constituição, cuja eficácia e força normativa também se impõem, aos particulares, no âmbito de suas relações privadas, em tema de liberdades fundamentais. III. SOCIEDADE CIVIL SEM FINS LUCRATIVOS. ENTIDADE QUE INTEGRA ESPAÇO PÚBLICO, AINDA QUE NÃO ESTATAL. ATIVIDADE DE CARÁTER PÚBLICO. EXCLUSÃO DE SÓCIO SEM GARANTIA DO DEVIDO PROCESSO LEGAL. APLICAÇÃO DIRETA DOS DIREITOS FUNDAMENTAIS À AMPLA DEFESA E AO CONTRADITÓRIO. As associações privadas que exercem função predominante em determinado âmbito econômico e/ou social, mantendo seus associados em relaçóes de dependência econômica e/ou social, integram o que se pode denominar de espaço público, ainda que não estatal. A União Brasileira de Compositores - UBC, sociedade civil sem fins lucrativos, integra a estrutura do ECAD e, portanto, assume posição privilegiada para determinar a extensão do gozo e fruição dos direitos autorais de seus associados. A exclusão de sócio do quadro social da UBC, sem qualquer garantia de ampla defesa, do contraditório, ou do devido 
associado foi excluído da União Brasileira de Compositores, sociedade civil sem fins lucrativos. No caso em questão, foi decidido que referida exclusão não poderia ocorrer sem a observância do contraditório e da ampla defesa. Entendeu-se que a autonomia privada não teria o condão de afastar a incidência das normas constitucionais que asseguram os direitos fundamentais dos associados, significando isto a incidência direta das normas constitucionais na relação privada mantida entre o associado e a União dos Compositores Brasileiros.

Outro exemplo pode ser encontrado na decisão do Supremo Tribunal Federal prolatada no RE 161243/ $\mathrm{DF}^{46}$, que versou sobre caso de empregado brasileiro da empresa aérea Air France, que pleiteou fosse aplicado a ele o Estatuo Pessoal da Empresa. O referido estatuto conferia vantagens aos empregados, porém só era aplicado àqueles de nacionalidade francesa. Assim, sob argumento do princípio da igualdade, o Estatuto Pessoal da Empresa também foi aplicado em favor do empregado brasileiro. Nota-se que a política interna de pessoal da empresa não deve se sobrepor aos direitos fundamentais previstos na constituição.

Verifica-se que, em ambos os casos, a autonomia privada não foi aniquilada. Isto porque, ela prevaleceu até o momento em que se verificou uma violação a

processo constitucional, onera consideravelmente o recorrido, o qual fica impossibilitado de perceber os direitos autorais relativos à execução de suas obras. A vedação das garantias constitucionais do devido processo legal acaba por restringir a própria liberdade de exercício profissional do sócio. $\mathrm{O}$ caráter público da atividade exercida pela sociedade e a dependência do vínculo associativo para o exercício profissional de seus sócios legitimam, no caso concreto, a aplicação direta dos direitos fundamentais concernentes ao devido processo legal, ao contraditório e à ampla defesa (art. 50, LIV e LV, CF/88). IV. RECURSO EXTRAORDINÁRIO DESPROVIDO.” (BRASIL. Supremo Tribunal Federal. RE 201.819/RJ. Relator para acórdão: Min. Gilmar Mendes. Julgamento: 11/10/2005. Órgão Julgador: 2a Turma. Publicação: DJ 27/06/2006).

46 "EMENTA: CONSTITUCIONAL. TRABALHO. PRINCÍPIO DA IGUALDADE. TRABALHADOR BRASILEIRO EMPREGADO DE EMPRESA ESTRANGEIRA: ESTATUTOS DO PESSOAL DESTA: APLICABILIDADE AO TRABALHADOR ESTRANGEIRO E AO TRABALHADOR BRASILEIRO. CF, 1967, art. 153, $\$ 1^{\circ} ; C F, 1988$, art. 5o, caput. I. - Ao recorrente, por não ser francês, não obstante trabalhar para a empresa francesa, no Brasil, não foi aplicado o Estatuto do Pessoal da Empresa, que concede vantagens aos empregados, cuja aplicabilidade seria restrita ao empregado de nacionalidade francesa. Ofensa ao princípio da igualdade: $C F, 1967$, art. $153, \S 1^{\circ} ; C F, 1988$, art. $5^{\circ}$, caput). II. - A discriminação que se baseia em atributo, qualidade, nota intrínseca ou extrínseca do indivíduo, como o sexo, a raça, a nacionalidade, o credo religioso, etc., é inconstitucional. Precedente do STF: Ag 110.846(AgRg)-PR, Célio Borja, RTJ 119/465. III. - Fatores que autorizariam a desigualização não ocorrentes no caso. IV. - R.E. conhecido e provido." (BRASIL. Supremo Tribunal Federal. RE 161243/DF. Relator: Min. Carlos Velloso. Julgamento: 29/10/1996. Órgão Julgador: 2a Turma. Publicação: DJ 19/12/1997). 
princípio que lhe era, concretamente, contraposto. No primeiro caso, isto se deu em relação à ampla defesa e ao contraditório; já no segundo, isto se deu em face $\mathrm{da}$ igualdade.

Nota-se que a incidência direta das normas constitucionais nas relações privadas não fulmina a autonomia das partes, mas, apenas, a compatibiliza com outros princípios que, no caso concreto, podem prevalecer.

\section{CONCLUSÃo}

Inicialmente, foi feito um breve histórico da evolução do direito civil, partindo-se da concepção outrora vigente de que o sistema se centrava no código civil. Abordou-se a questão da ideologia individualista e voluntarista que permeou referido ideário e pretendia conferir estabilidade e segurança às relações privadas, livre de interferências externas. Consequência disto foi a pretensão de completude e perenidade do código civil. Com a sua completude, pretendeu-se conferir uma autossuficiência ao sistema nele concretizado. Já com a sua permanência, pretendeu-se manter as relações civis livres da influência das vicissitudes próprias da sociedade, tais como guinadas políticas repentinas e revoluçôes, que representariam um fato de instabilidade às relaçõos privadas.

Consequência dessa visão do direito civil era o afastamento da incidência da constituição sobre as relações privadas. A incidência da constituição se dava mais sobre o legislador, mormente no que se refere à concepção da estrutura do Estado. E mesmo com relação à superação de lacunas do sistema, primordialmente estas eram resolvidas dentro do próprio sistema do código civil, que se pretendia fechado.

Fase seguinte dessa evolução se deu no contexto da complexificação das relaçôes sociais, principalmente com o advento da revolução industrial. O sistema centralizado no código já não mais dava conta das necessidades da sociedade, de modo que foi iniciada a fase da edição das legislações extravagantes. Se, em um primeiro momento, as legislações setoriais somente se prestavam a regular matérias episódicas não contempladas no código, em um momento posterior a profusão de novas legislações específicas fez com que o código civil perdesse a centralidade, reservando-se a ele somente a disciplina do direito comum.

Também na esteira da maior complexidade das relações sociais, notou-se que não só o Estado seria uma ameaça a direitos dos particulares, mas, também, outros particulares. Então, foi percebida a necessidade de maior intervenção do Estado para responder aos reclamos daí decorrentes. Começaram, assim, a surgir as constituições de maior cunho social, inaugurando essa fase a Constituição de Weimar, de 1919. Essa tendência se acentuou após a Segunda Grande Guerra, com a edição 
de constituições que traziam em si normas de caráter social bastante acentuado, tais como a da Itália, de 1948; da República Federal da Alemanha, de 1949; de Portugal, de 1976; e a do Brasil, de 1988. Todas elas corporificaram um mudança de paradigma axiológico do individualismo para o solidarismo.

Em um cenário no qual coexistem a constituição com acentuado cunho normativo, leis extravagantes e códigos, foi preciso estabelecer a forma de interconexão lógica entre eles. Daí a concepção da constituição como o elemento central do sistema, a espraiar seus princípios e valores por todo o ordenamento, sistematizando-o e conferindo unidade a ele.

E a colocação da constituição, com força normativa, no ápice do ordenamento, acabou por tornar ilógica qualquer tese que sustente a existência de espaços de não direito. Afinal, os princípios e valores constitucionais são aplicados à totalidade do ordenamento. A totalidade do ordenamento será informada pelos mesmos princípios e valores, conferindo-se unidade ao sistema, impedindo-se que esse se apresente de maneira fragmentada. Aliás, eventual fragmentação seria a própria negação das noções de sistema e ordenamento.

$\mathrm{Na}$ inexistência de fragmentação, a decorrência lógica é a inexistência de "fendas" legislativas. Sendo assim, todos os fatos, por mais prosaicos que sejam, terão uma valoração jurídica, ainda que não expressa no ordenamento. Não há, portanto, fatos irrelevantes para o direito.

Por fim, foi analisada a questão acerca da forma pela qual se dá a incidência da constituição nas relações privadas. Já de plano, o fato de não haver fendas legislativas já leva à conclusão de que, ao menos nos espaços deixados pelo legislador ordinário, os valores e princípios constitucionais incIdem de forma direta.

O passo seguinte foi analisar se a incidência direta também ocorre mesmo nos casos em que o legislador ordinário não se encontra omisso. E tal omissão se dá, basicamente, em suas situações. A primeira delas, é aquela em que o legislador ordinário, embora não tendo sido omisso, institui lei inconstitucional. Nesse caso, foi a própria incidência direta das normas constitucionais que conduziu à inconstitucionalidade da lei. Entendeu-se por inconstitucional a lei exatamente pelo fato de ela ter caminhado contrariamente a um preceito constitucional. E se não há fendas legislativas, mesmo antes de ocorrer a declaração formal de inconstitucionalidade, a relação jurídica já é regulada pela norma constitucional.

A segunda situação a ser considerada é aquela na qual o legislador não foi omisso, regulando determinada matéria mediante lei constitucional. Nesse caso, ainda assim não há que se falar em incidência indireta da constituição. Caso contrário, conduzir-se-ia a uma situação de enfraquecimento da força normativa da 
constituição. Afinal, em última análise, seria atribuir ao legislador ordinário a definição acerca do grau de força normativa da constituição em cada caso. Isto consistiria uma subversão do sistema, eis que a eficácia da lei maior seria conformada por alguém que lhe está abaixo.

Assim, reafirma-se que a tábua de valores constitucionais se aplica à totalidade do ordenamento, independendo, para tanto, de considerações acerca da atuação do legislador ordinário.

\section{REFERÊNCIAS}

BODIN DE MORAES, Maria Celina. A caminho de um direito civil-constitucional. $\mathrm{Na}$ medida da pessoa humana. Rio de Janeiro: Renovar, 2010, p. 3-20.

CANOTILHO, José Joaquim Gomes. Direito constitucional e teoria da Constituição. 7. ed. Coimbra: Almedina, 2003.

HESPANHA, António Manuel. Cultura jurídica europeid: síntese de um milênio. Coimbra: Almedina, 2012.

PERLINGIERI, Pietro. Perfis do direito civil. 3. ed. Rio de Janeiro: Renovar, 2002.

PERLINGIERI, Pietro. $O$ direito civil na legalidade constitucional. Rio de Janeiro: Renovar, 2008.

PINTO, Carlos Alberto da Mota. Teoria geral do direito civil. 4. ed. Coimbra: Coimbra Editora, 2012.

RIBEIRO, Joaquim de Sousa. Constitucionalização do direito civil. In: Boletim da Faculdade de Direito da Universidade de Coimbra, v. 74, p. 729-755, 1998.

SARMENTO, Daniel. A normatividade da constituição e a constitucionalização do direito privado. Revista da EMERJ, v. 6, n. 23, p. 272-297, 2003. Disponível em: <http:// www.emerj.tjrj.jus.br/revistaemerj_online/edicoes/revista23/revista23_272.pdf>. Acesso em: 30 set. 2017.

SARMENTO, Daniel. A vinculação dos particulares aos direitos fundamentais no direito comparado e no Brasil. In: BARROSO, Luis Roberto (Org.). A reconstrução democrática do direito público no Brasil. Rio de Janeiro: Renovar, 2007, p. 293-365.

SCHREIBER, Anderson. Direito civil e Constituição. In: Direito civil e Constituição. São Paulo: Atlas, 2013, p. 5-24.

SCHREIBER, Anderson; KONDER, Carlos Nelson. Uma agenda para o direito civil constitucional. IBDCivil, v. 10, 2016. Disponível em: <https://www.ibdcivil.org.br/image/data/revista/volume10/rbdcivil_vol_10_02_doutrina-nacional_uma-agenda.pdf>. Acesso em: 04 out. 2017.

STRECK, Lênio. Hermenêutica jurídica e $(m)$ crise: uma exploração hermenêutica da construção do direito. Porto Alegre: Livraria do Advogado, 1999. 
•. Direito Civil: Estudos | Coletânea do XV Encontro dos Grupos de Pesquisa - IBDCivil

TEPEDINO, Gustavo. Normas constitucionais e direito civil. Revista da Faculdade de Direito de Campos, v. 5, n. 4, p. 167-175, 2003-2004. Disponível em: <http://www.uniflu. edu.br/arquivos/Revistas/Revista04e05/Docente/10.pdf>. Acesso em: 30 set. 2017.

TEPEDINO, Gustavo. Normas constitucionais e relações de Direito Civil na experiência brasileira. Temas de direito civil. Rio de Janeiro: Renovar, 2006, Tomo 2, p. 21-46.

TEPEDINO, Gustavo. Normas constitucionais e direito civil na construção unitária do ordenamento. In: Temas de direito civil. Rio de Janeiro: Renovar, 2009, Tomo 3, p. 3-19.

TEPEDINO, Gustavo. As relaçôes de consumo e a nova teoria contratual. Disponível em: $<$ http://www.egov. ufsc.br/portal/sites/default/files/anexos/8788-8787-1-PB.pdf>. Acesso em: 04 out. 2017. 